\title{
The spatial distribution of industries in transitional China: A study of Beijing
}

\author{
Jiaming Li ${ }^{\mathrm{a}}$, Wenzhong Zhang ${ }^{\mathrm{a}}$, Hongxia Chen ${ }^{\mathrm{b}}$, Jianhui $\mathrm{Yu}^{\mathrm{a},{ }^{*}}$ \\ a Institute of Geographic Sciences and Natural Resources Research (CAS), University of Chinese Academy of Sciences, 100101, Beijing, China \\ ${ }^{\mathrm{b}}$ School of Government, Central University of Finance and Economics, 100081, Beijing, China
}

\section{A R T I C L E I N F O}

\section{Article history:}

Received 22 August 2014

Received in revised form

20 March 2015

Accepted 12 May 2015

Available online 20 May 2015

\section{Keywords:}

Industrial spatial pattern

The dual power of government and market

Transitional economy

Beijing

\begin{abstract}
A B S T R A C T
The paper aims to provide a complete picture of the spatial distribution of industries in China, a country which is presently undergoing a transition from a planned economy to a market economy. It also seeks to explore the reasons behind that distribution. We employ the negative exponential function to analyze the spatial distribution of 57 economic sectors in Beijing. Comparison of the preferred location of each sector can reveal the overall industrial spatial pattern, which functions as a spatial reflection of the influence of the government and the market on economic activities. The findings of the study suggest that the governmental force is more powerful than the market force in the urban core, although the overall spatial distribution of industries is found to comply with the laws of the market economy. The power of the government and the market also shape the industrial spatial pattern in other Chinese cities, in ways that are similar to the case of Beijing.
\end{abstract}

๑) 2015 Elsevier Ltd. All rights reserved.

\section{Introduction}

The spatial distribution of the activities of various economic sectors lies at the very heart of theories of urban spatial structure. The concentric model, developed by Burgess, describes urban space in terms of a series of concentric rings, which radiate out from the central business district to include the factory zone, the workingclass zone, the better housing zone, and finally the commuters' zone. The monocentric city model, which is rooted in von Thunen's model of agricultural land and which was further developed by Alonso, Muth, and Mills in the 1960s, depicts a similar land-use pattern of rings and is similarly based on ideas of market equilibrium. The common basis of these theories lies in their assumption of the existence of a competitive market. These theories have been widely used in Western countries and have been proven to have explanatory power; however, the applicability of these theories to cities in a transitional economy such as China's is yet to be decided.

China is presently undergoing a transition from a planned economy to a market economy, and political and administrative powers currently exert as much influence on the country's socio-

\footnotetext{
* Corresponding author.

E-mail addresses: lijm.12b@igsnrr.ac.cn (J. Li), zhangwz@igsnrr.ac.cn (W. Zhang), chenhongxiasff@163.com (H. Chen),yujh@igsnrr.ac.cn (J. Yu).
}

economic development as the market does. Many scholars have recognized this and have subsequently begun to pay more attention to the roles played by institutions when studying Chinese issues. Tisdell (2009), for instance, emphasizes the importance of taking political and social settings into account when attempting to understand China's development, given that the nation's political system has changed so little in comparison with the major changes experienced by the economic system. Other empirical studies have also focused on the influence exerted by the transitional economy on the transformation of socio-spatial structure and land use (Ma, 2002; Wu \& Yeh, 1997).

Current studies of Beijing's urban spatial structure tend to focus on issues of suburbanization, population densities, and housing and land prices (Ding, 2004; Li, 2000; Zhou \& Ma, 2000). Far fewer studies, however, have attempted to shed light on the locations of industrial sector activities (Liu, Han, \& O'Connor, 2013; Ren \& Sun, 2012), an omission which is probably due to the lack of precise location data for firms. The spatial distribution of industries is typical of the spatial distribution of many other land uses in that it is greatly affected by both market forces and by government interventions. The industrial spatial pattern of a city can thus be understood as the spatial reflection of the economic activities which occur there, economic activities which in turn are affected significantly by the dual powers of the government and the market. In attempting to reveal the dual 
influence of government and market forces on the urban spatial structure of Beijing and the activities which compose it, this paper therefore choses to so specifically from the perspective of industrial space.

The paper is organized as follows. The following section reviews the major theories that can be deployed to explain the location of the activities of specific industrial sectors and industrial production as a whole. Section 3 defines the study area, and introduces the data and methodology used in this study. Section 4 sets out an empirical analysis of intra-urban firm locations; the spatial pattern of industrial sectors in their distribution within the urban area of Beijing (as derived by the analysis) is also described here. Section 5 discusses the major factors that affect industrial location choice and land use. Finally, Section 6 discusses the impact of this pattern on Beijing and on other Chinese cities.

\section{Theory: the spatial distribution of industries}

Burgess's concentric zone model is one of the earliest theoretical models to explain urban land-use structure. Based on a study of Chicago, the model describes the spatial arrangement of businesses, industries, and residential districts in a city as the result of competition amongst, invasion by, and succession of different land uses. While it is recognized that the concentric zone model is an ideal type rather than a representation of reality (Pacione, 2005), scholars who disagree with the concentric zone model and attempt to find alternative patterns are forced to recognize the prevailing popularity of this model (Dear, 2002). The model has been repeatedly tested in Western cities such as Chicago (Greene \& Pick, 2011), as well as in cities in less developed countries such as Beijing (Gu, Wang, \& Liu, 2005; Tian, Wu, \& Yang, 2010; Xiao et al., 2008).

The other important model that is used to interpret urban spatial structure is the monocentric model, which serves as the foundation of all spatial analysis of urban structure. In comparison to Burgess's concentric model, the monocentric model is built in a more rigorous manner, in accordance with neoclassical economic theories. Nevertheless, the monocentric model also emphasizes the competitive relationship between economic activities and derives similar annular patterns with respect to urban land use. The model fully recognizes the influence of market forces on the formation of urban spatial structure. Based on the bid rent theory (Alonso, 1960a; 1960b; 1964), land use and land price are thereby determined on the basis of the economic activities that will pay the highest price. The model essentially translates multiple targets of each activity into two dimensions: the cost of land, and distance from the Central Business District (CBD). The bid rent curve of each economic sector emerges as the result of the tradeoff between the cost of land in a given location and the transport cost from that location to the CBD. Owing to differences in production and transport rates, each economic sector produces a specific bid rent curve. Those activities with a more steeply sloped and more highly intercepted bid rent curve are those which win locations that are closer to the CBD. If individual activities are ranked by the steepness of their bid rent curves, all urban sites are occupied by the industry paying the highest rent, and thus urban land is used efficiently (Balchin, Bull, Kieve, \& Balchin, 1995; Fujita, 1986; Jones et al., 1991). As a result, the model describes a theoretical urban spatial structure in which business activities concentrate in the city center, housing locates in suburban areas, heavy manufacturing firms spread out on the outskirts of a city, and agricultural uses occupy the outermost regions. Notably, the kind of urban space derived from the monocentric model is a continuous (rather than discrete) space, made up of various land uses.

A large number of empirical studies have provided evidence in support of the interpretive power of the monocentric model. However, while most of the literature has examined negatively sloped residential land and housing prices, fewer studies have focused on the spatial distribution of activities undertaken within a specific industrial sector, and even fewer studies have examined the entire list of all the industrial sectors. This is probably due to a lack of data. For example, Chudzynska (1981) and Riley (1997), who independently undertook studies of the spatial structure of the retail industry in Warszawa and Lodz respectively, both found an annular pattern in the distribution of retail-sector activities, wherein higher-order activities tended to locate in the city center and lower-order activities in the periphery. Similarly, Scott (1967) also argued that the monocentric model was able to describe the organization of retail activities in London. A number of studies have provided evidence that the bid rent model is also applicable in relation to the hotel and office sectors (Dunse, Jones, Brown, \& Fraser, 2005; Egan \& Nield, 2000). The model therefore successfully explains the distribution of a range of different industrial activities (Anas, Arnott, \& Small, 1998; Sivitanidou, 1996). To the author's knowledge, however, few studies have examined the spatial distribution of activities associated with all of the sectors that make up industrial production in one urban area.

The classical model has also been criticized for not taking other critical factors into account. Many scholars have argued that nonmarket factors - including street networks, arterial routes, planning regulations such as land-use and building height controls, morphological barriers, congestion and pollution, etc. - exert an undeniable influence on the spatial distribution of economic activities (Archer \& Smith, 2003; Bertaud \& Brueckner, 2005; Brown, 1993; Ellson \& McDermott, 1987; Grimaud, 1989; Hills \& Schleicher, 2010; Hsu \& Guo, 2001; Peiser, 1987). Under the influence of these factors, the spatial distribution of industrial activities hardly resembles that predicted by the monocentric model; moreover, the urban space they produce is, in reality, not smooth but rather characterized by subsidiary peaks. In polycentric cities, even positive rent gradients can exist (Cropper \& Gordon, 1991; Dubin \& Sung, 1987; Richardson, 1977).

In the transitional economy, which is characterized by the coexistence of government power and market power (Wu \& Yeh, 1999), political power and institutional settings are considered to exert at least equal, if not greater, influence than market forces on the formation of urban spatial structure. For example, in Russia, due to the occupation of prime central locations by industrial uses, people live in suburban high-rise residential buildings, leading to a positive population density gradient (Bertaud \& Renaud, 1997). In China, since the PRC was established in 1949, national and local industrial policies have also strongly shaped the spatial distribution of industry in urban areas. In the 1950s, the Soviet Union implemented 156 major industrial projects, which formed not only the country's industrial framework but also the industrial spatial structure for the cities involved. In the 1960s, China experienced a severe period of resource and material scarcity, and under the national strategy of "production first, living conditions second," land in central locations was mostly occupied by state-owned manufacturing firms (Cheng, Boerboom, \& Geertman, 2012). Until the late 1980s, when the country experienced a decade of economic reform, the market started to play a role in resource allocation and in determining prices (although government interventions remained pivotal in promoting economic development and influencing industrial development). Since the 1990s, many large Chinese cities have undergone processes of industrial decentralization, which has occurred through the implementation of government policies, namely "retire the secondary industries and advance the tertiary industries" (tui er jin san) and "vacating the cage (land) to change the bird (upgrade industries)" (teng long huan niao) (Feng \& 
Zhou, 2005; Ye, 2011, 2014).

Meanwhile, scholars and government officials in China have gradually come to recognize the economic inefficiency of cities without a Central Business District (CBD) or industrial concentration; in response to this realization, local governments have begun to invest heavily in old downtown regeneration and CBD construction, as well as in industrial park development. In fact, these two processes - the regeneration of old downtowns and the construction of industrial parks and development zones in the suburbs - should be seen as being complementary. Local governments construct the latter (and give them preferential tax status) because they want manufacturing enterprises to relocate from the inner city to the suburbs, instead of moving out of the city. Current studies prove that this strategy works to the extent that these development zones act as an important factor in the industrial location in the intra-city areas (Huang \& Wei, 2014; Wei, Leung, Li, \& Pan, 2008; Wu, 1999; Wu \& Radbone, 2005), attracting a large number of enterprises and dramatically changing the industrial spatial pattern of Chinese cities (Shi \& Huang, 2012; Yeup \& Zhang, 2008). Addressing the Beijing context more specifically, Feng, Zhou, and Wu (2008) consider the development zones to be a significant factor in the industrial urbanization of the capital. More recently, another trend in the form of new administration center development is evident across the country. When government buildings are relocated to a more suburban location, businesses, housing, and certain industrial uses tend to follow, while other land uses stay in previous locations. In all of these cases, the spatial distribution of industrial activities is affected (Wang, Kundu, \& Chen, 2010).

As the political center of China and as a city that is undergoing dramatic changes, Beijing has attracted a lot research interest. Some of the hottest topics addressed by scholars in recent years include suburbanization, the development of commercial and housing markets, land expansion and urban sprawl, and social and spatial structure change (Ding, 2004; Feng et al., 2008; Li, 2000; Wong \& Zhao, 1999; Wu \& Phelps, 2011; Zhou \& Ma, 2000). Relatively fewer studies have focused on industrial development and its spatial arrangement (Gao et al.; 2014; Liu et al., 2013; Ren \& Sun, 2012), and these studies draw their conclusions mainly from case studies and are often focused on one single sector. One important question therefore remains unexamined: what is the spatial distribution of all industrial activity in Beijing? This paper tries to contribute to both answering this question and to investigate the reasons behind current patterns.

\section{Study area, data, and method}

\subsection{The study area}

Beijing has been the national political center of China since the Yuan dynasty (13th century), and now the city aims at becoming a global city. In 2010, Beijing's gross domestic product (GDP) was 141.1 billion Yuan, with the service sector accounting for more than $70 \%$ of that figure. In the same year, the city accommodated 19.61 million people in an area of $16,800 \mathrm{~km}^{2}$. Tiananmen Square is usually considered to be the city center, with the Forbidden City (the imperial palace of the Ming and Qing dynasties, from the 14th century to the early 20th century) abutting the northern edge of the square, and the Zhongnanhai (the old imperial garden which now houses the headquarters of the Communist Party of China and the State Council) also adjacent to the square. Urban development used to be confined inside the Second Ring Road, which is built on ruins of the old wall, however since the rapid urban expansion of the 1990s and the construction of development zones and new towns, this boundary has shifted (Jiang, Liu, Yuan,
\& Zhang, 2007; Tan, Li, Xie \& Lu, 2005). In 1988, the Zhongguancun Science Park (ZSP) was initiated between the Third and Fourth Ring Roads in order to develop the information and telecommunication technology sectors (ICT). Since then, sub-parks of the ZSP have been constructed in all of Beijing's new towns, so the ZSP have spreaded out over all of Beijing. In the 1990s, the Beijing Economic and Technological Development Area (BDA) was established in Yizhuang, which was a small town far from city center. From then on, the Beijing municipality approved CBD and a series of industrial parks, like Fengtai industrial park (ZSP) and Dianzicheng. Fig. 1 shows the spatial distribution of these development zones and new towns in Beijing.

Whilst some scholars began to argue that Beijing had become a polycentric city (Ma, 2004), the monocentric model still worked in Beijing, with the distance to Tiananmen Square fundamentally influencing both the price of land and population densities (Zheng \& Kahnm, 2007). The Beijing metropolitan area is divided into 22 ring zones, determined in accordance with their distance from the city center (a new ring starts every $5 \mathrm{~km}$ ). The space of each ring, which together stretch more than $100 \mathrm{~km}$ from the city center, is regarded as one area. The area within the Fifth Ring Road is divided by another set of ring roads. The ring road system has played an important role in shaping Beijing's urban space, and in particular it has influenced the distribution of industrial activities in the city, in concert with a range of regulatory policies and plans - for example, as was the case in 2000 , when the City published an official document requiring all industrial enterprises located inside the Fourth Ring Road to gradually move out.

Two simple curves describe the general spatial distribution of the manufacturing and service industries in Beijing (these are shown in Fig. 2). The slopes of both curves become positive at a distance of between 60 and $70 \mathrm{kms}$ from the city center, which is followed by a gradual decline in the number of enterprises as the distance from the center increases. The subsequent points at which the curve adopts a positive gradient mark the location of other city centers (Craig \& Ng, 2001). Outside of the $60-\mathrm{km}$ radius, the manufacturing and service industries only locate in Beijing's outer suburbs and counties, such as Yangqing and Miyun. Because within this study we aimed to draw a complete picture of the spatial distribution of industry within one city, this research primarily addresses the area within a $60-\mathrm{km}$ radius of the city center.

\subsection{Data}

This study employed two unique data sets. The first data set, a plant-level data set, detailed all enterprises registered with the Beijing Administration for Industry and Commerce in 2010. The data set covers 57 sectors and a total of 540,698 enterprises (43,102 manufacturing enterprises and 457,569 service enterprises). The 57 sectors consist of 27 manufacturing sectors and 30 service sectors; social service sectors such as electricity, gas, and sanitary services, zoos, schools, and hospitals are not included. For each sector, the number of enterprises ranged from 200 (in the railroad transportation industry) to 113,713 (in the technology promotion services), with an average number of 9000 enterprises. The second data set included information on all land parcels that were leased to developers by the Beijing Land Authority through open auction, from 1992 to 2010. This latter data set was helpful in understanding the industrial spatial pattern in Beijing.

\subsection{Method}

Whilst many non-parametric estimation methods fit the distribution of a given data precisely, it was difficult to locate 


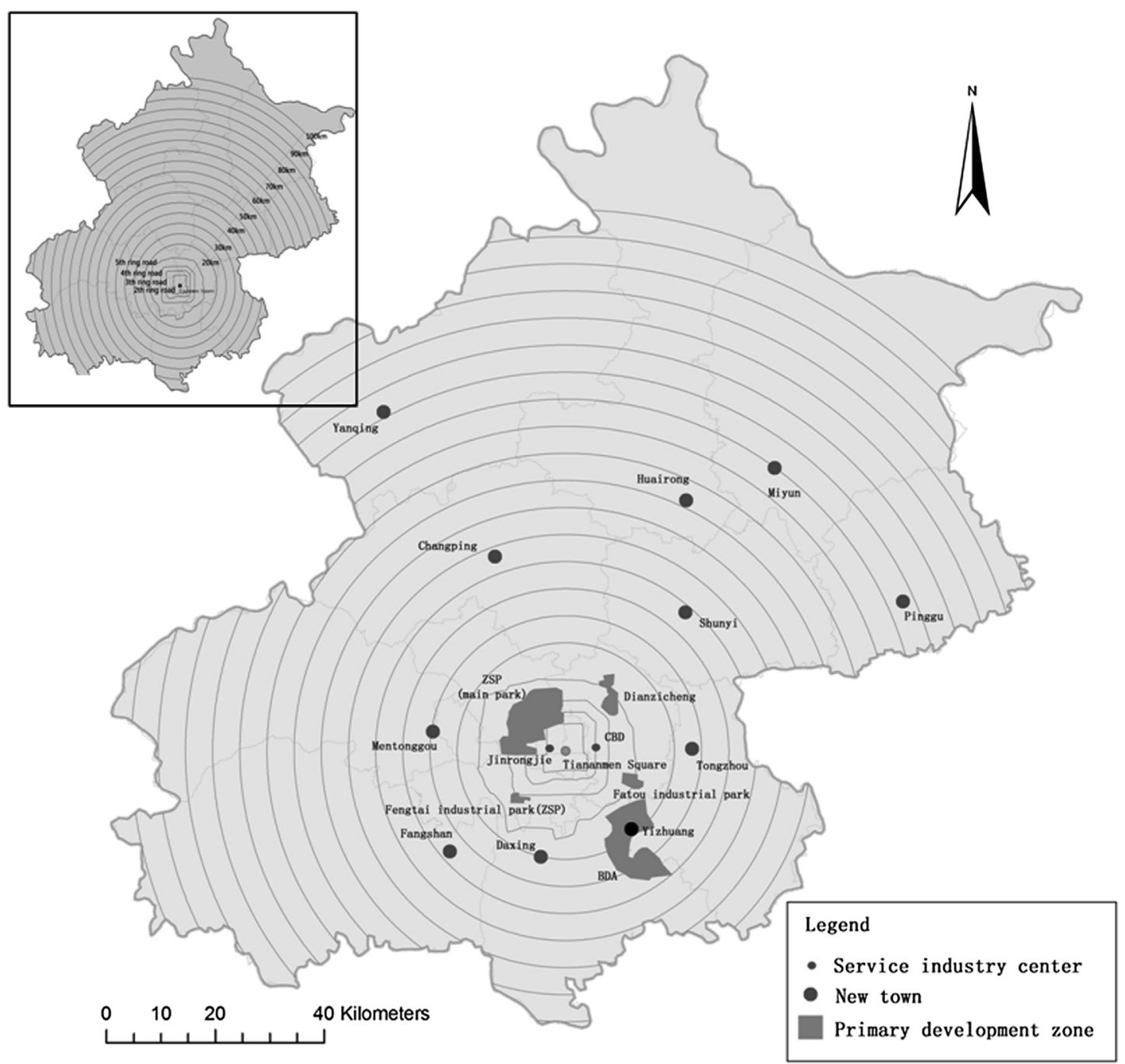

Fig. 1. The study area of Beijing.

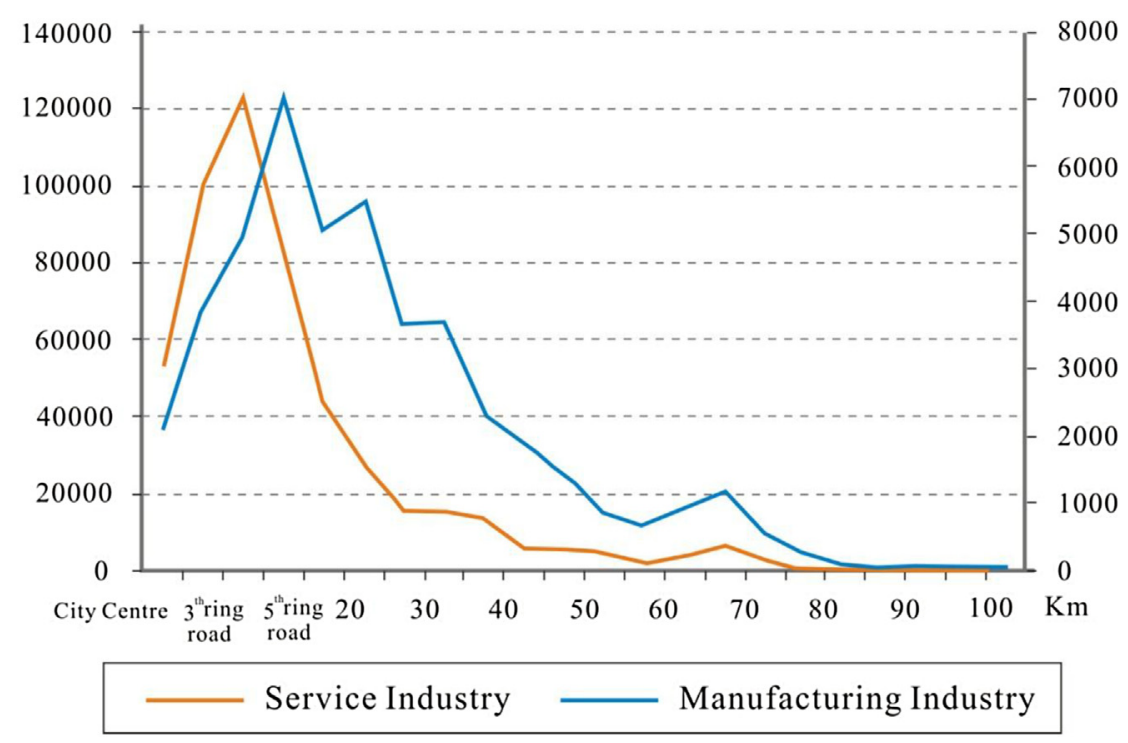

Fig. 2. The spatial distribution of enterprises from the manufacturing and service industries. 
discrepancies between sectors in an analysis that required the overlay of 61 graphs of the distribution of enterprises. It was therefore considered reasonable to employ a suitable function to fit the data and generate parameters to analyze the characteristics of each sector. As such, we employed the negative exponential function, originally developed by Colin Clark (1951) to study population density. Arguing that this function would be best viewed as a descriptive tool, Kemper and Schmenner (1974) applied it to describe the distribution of manufacturing enterprises in five metropolitan areas. In order to achieve comparability across the different sectors, we calculated the share of the number of enterprises in each ring zone for every sector, and then employed the negative exponential function in order to fit the share. We also compared the results of the negative exponential function with those of a simple linear function, with the outcome of this comparison demonstrating that the former was better (the average RSquare was 0.862 and 0.827 , respectively). The expression for the function is:

$n_{x}=n_{0} e^{-b x}$

where $n_{x}$ is the share of the number of enterprises in sector $n$ at distance $x$ from the sector center, $n_{0}$ is the share in the zone with the largest number of enterprises, and $b$ is the slope of the fitting curve, indicating the rate of diminution of the share of the number of enterprises with increasing distance from the industry center.

Calculating the share of the number of enterprises in a certain zone for each sector provides an indication of that particular sector's location preference. The fitting curve of a certain sector thus demonstrates that sector's location preference within the entire urban area. The zone with the largest share of enterprises from a given sector - in other words, the zone that accommodates the "center" for a given sector - is the most preferred location for that sector.

Fitting the distribution of enterprises was complicated: few enterprises in the manufacturing and service sectors were found to be located within the innermost ring zone - in fact, no one sector is concentrated there. Of the 57 centers analyzed, 3 manufacturing sectors were found to have their centers in the area between Third and Fourth Ring Roads, 10 sectors have centers located between the Fourth and Fifth Ring Roads, 2 sectors have centers between 15 and $20 \mathrm{~km}$ from the city center, and 12 sectors have centers between 20 and $25 \mathrm{~km}$ from the city center. In addition, the centers of 14 service sectors were located between the Second and Third Ring Roads, the centers of 13 sectors were located between the Third and Fourth Ring Roads, and the centers of 3 sectors were located between the Fourth and Fifth Ring Roads. These results meant that one curve could not adequately depict the spatial distribution, and that two curves were in fact required in order to fit each sector. The spatial distribution of enterprises thus tended to first increase, and then decrease, as distance from the city center increased. As such, we first divided the urban space of the study area into two parts, using the location of each sector's center, and then estimated two fitting curves to model the spatial distribution of these industries. The difference between the slopes of these two fitting curves reflects the different characteristics of industrial development in two directions (one towards the city center, and the other towards the city periphery). The negative exponential function was found to be much better than a linear function in fitting the spatial distribution of enterprises in the area outside the zone accommodating the industry's center. The average R-square of the negative exponential function was up to 0.857 , while the value of the linear function was 0.768 . The following sections provide more detail with respect to the estimations and findings.

\section{The spatial distribution of industrial sectors in Beijing}

\subsection{Manufacturing and building location}

The results of the analysis revealed that 24 of the 27 manufacturing sectors considered in this study were clustered outside of the Fourth Ring Road, while 27 of the 30 service sectors were located within the Fourth Ring Road (inner urban area). In addition, $74.47 \%$ of all manufacturing firms were found to be located outside the Fourth Ring Road. This suggests a decentralized and dispersed location pattern amongst most manufacturing sectors in Beijing. This finding is in accordance with other decentralization studies in Chinese cities (Zhou \& Ma, 2000). Factors like large land supply, low land prices, and improved transportation could account for this industrial decentralization pattern. In addition, industrial polices like "retire the secondary industries while advance the tertiary industries" (tui er jin san), which were implemented since the 1990s, have also contributed to the decentralized industrial location pattern (Ye, 2014). Since the market economy is still under development and the command economy remains in many areas, government policies tend to be more influential on firms' location choice (especially state-owned firms) than the market factors (Wu \& Phelps, 2011).

Four preferred locations for manufacturing sectors were discerned, based on the results of the study. Each of these four zones has a leading industry: 3 high-tech industries are centered between the Third and Fourth Ring Roads; machinery and equipment manufacturing sectors are located between the Fourth and Fifth Ring Road; and raw material processing are located in another two zones. Beyond the discrepancy which can be noted among sectors in terms of their most preferred location, the slopes of fitting curves are even more important in terms of showing differences in spatial distribution. This is especially true for those sectors which are centered in the same area. A fitting curve with a large slope indicates that the industrial space is narrow and small in scope for a particular sector. As such, a large b-value $\left(b^{\prime}\right)$ in this study means that the industrial space of a given sector does not expand towards the city center, but rather towards the urban periphery. That the value of $b+b^{\prime}$ is positive in turn indicates that the industrial space tends to expand towards the urban periphery and vice versa.

In contrast to most of manufacturing sectors centered outside the Fourth Ring Road, the computer and communication equipment sector and the electric equipment sector were both found to be concentrated inside the Fourth Ring Road, as Table 1 and Fig. 3 show. But the steep slope of their fitting curves show that even these high-tech manufacturing activities do not expand towards the city center easily. The urban core area (that is, inside the Second Ring Road) is, pursuant to the findings of this study, still not the ideal place for manufacturing. More than one quarter of enterprises engaged in the computer and communication equipment sector and more than one fifth of the enterprises engaged in the instruments and office equipment sector were found to be concentrated in the area between Third and Fourth Ring Roads. The degree of concentration of pharmaceutical industries was, however, found to be low.

Most of sectors centered between the Fourth and Fifth Ring Roads tended to extend to the urban periphery rather than to city center, as shown in Table 2 . The only sectors found to have larger $\mathbf{b}^{\prime}$ values were the printing and leather industries. In modern society, nearly all economic activities require printing services; as such, enterprises working within that sector are likely to be located within the urban area. Given the small number of enterprises engaged in the leather sector, this result is unlikely to indicate a broader trend for industrial production as a whole. The number of leather enterprises accounts for just $0.4 \%$ of the total number of 
Table 1

Fitting results for manufacturing sectors centered between the Third and Fourth Ring Roads.

\begin{tabular}{|c|c|c|c|c|c|c|}
\hline \multirow[t]{2}{*}{ Sector } & \multirow[t]{2}{*}{$n_{0}$} & \multirow[t]{2}{*}{$\mathrm{b}$} & \multirow[t]{2}{*}{$\mathrm{b}^{\prime}$} & \multirow[t]{2}{*}{$\mathrm{b}+\mathrm{b}^{\prime}$} & \multicolumn{2}{|l|}{ R Square } \\
\hline & & & & & Exponential & Linear \\
\hline Computer and communication equipment & $26.01 \%$ & 0.627 & -0.434 & 0.193 & 0.970 & 0.857 \\
\hline Instruments and office equipment & $22.18 \%$ & 0.578 & -0.401 & 0.177 & 0.960 & 0.891 \\
\hline Pharmaceutical industry & $16.78 \%$ & 0.284 & -0.288 & -0.004 & 0.871 & 0.892 \\
\hline
\end{tabular}

Note: $\mathrm{b}$ for fitting curves from industry centers to the city center; $\mathrm{b}^{\prime}$ for fitting curves from industry centers to the urban periphery.

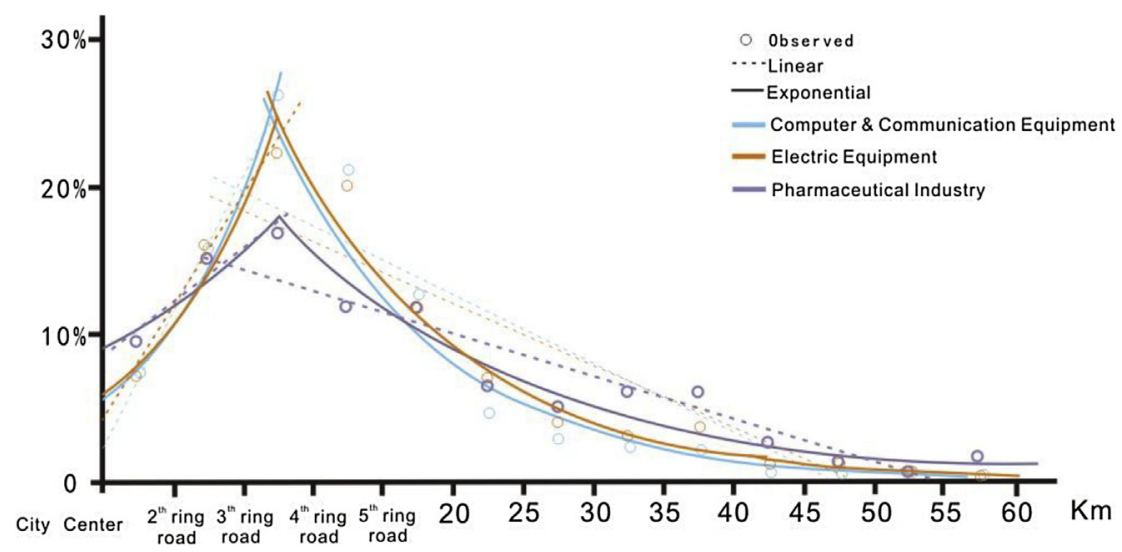

Fig. 3. Spatial distribution of manufacturing sectors centered between the Third and Fourth Ring Roads.

Table 2

Fitting results for manufacturing sectors centered between the Fourth and Fifth Ring Roads.

\begin{tabular}{|c|c|c|c|c|c|c|}
\hline \multirow[t]{2}{*}{ Sector } & & \multirow[t]{2}{*}{$\mathrm{b}$} & \multirow[t]{2}{*}{$\mathrm{b}^{\prime}$} & \multirow[t]{2}{*}{$\mathrm{b}+\mathrm{b}^{\prime}$} & \multicolumn{2}{|l|}{ R Square } \\
\hline & & & & & Exponential & Linear \\
\hline Beverages & $11.02 \%$ & 0.616 & -0.096 & 0.52 & 0.751 & 0.7845 \\
\hline Rubber industry & $13.28 \%$ & 0.6 & -0.274 & 0.326 & 0.7805 & 0.876 \\
\hline Transportation equipment & $19.61 \%$ & 0.528 & -0.251 & 0.277 & 0.8775 & 0.8265 \\
\hline Apparel and other textile products & $25.65 \%$ & 0.439 & -0.296 & 0.143 & 0.837 & 0.6725 \\
\hline Industrial machinery and equipment & $13.72 \%$ & 0.41 & -0.248 & 0.162 & 0.9195 & 0.9475 \\
\hline Electronics and other electric equipment & $16.81 \%$ & 0.406 & -0.307 & 0.099 & 0.979 & 0.965 \\
\hline Special industry machinery & $16.56 \%$ & 0.346 & -0.331 & 0.015 & 0.86 & 0.8695 \\
\hline Leather and leather products & $15.47 \%$ & 0.208 & -0.323 & -0.115 & 0.778 & 0.7825 \\
\hline Textile mill products & $10.63 \%$ & 0.2 & -0.193 & 0.007 & 0.9185 & 0.914 \\
\hline Printing services & $14.01 \%$ & 0.129 & -0.248 & -0.119 & 0.7035 & 0.6685 \\
\hline
\end{tabular}

Note: $\mathrm{b}$ for fitting curves from industry centers to the city center; $\mathrm{b}^{\prime}$ for fitting curves from industry centers to the urban periphery.

enterprises considered in the study. Another special sector is the rubber industry. The relatively large slopes of two fitting curves but relatively small share in between the Fourth and Fifth Ring Roads demonstrates a lack of suitable space for this industry.

The values of $b+b^{\prime}$ were found to be negative for nearly half of the sectors centered in another two areas, and even for sectors with a positive value, smaller absolute values of $b+b^{\prime}$ and larger $b^{\prime}$ values reveal that the degree of expansion to the urban periphery is smaller than in sectors centered between the Fourth and Fifth Ring Road. This implies that manufacturing enterprises do not escape as far away from the city center as might be possible, even if the decentralization of manufacturing is a clear trend in Beijing (Zhou \& Ma, 2000). As Table 3 shows, raw material processing industries such as the stone, clay, and glass products sector tend to locate far away from city center and light industries such as the crafts sector and the pens, pencils, and sporting goods sector are the opposite. Whilst it seems that there are exceptions to this tendency, such as in the case of the furniture industry and the non-ferrous metal processing sector, in fact both of these sectors are heavily concentrated in their respective sector centers (which accommodate a share of $24.54 \%$ and $16.85 \%$ of all enterprises, respectively), and their expansion trends are significant in neither direction. The chemicals industry may be the only true exception in this respect.

In general, the findings of this study indicate that whilst the manufacturing sectors do tend to expand towards the urban periphery, the decentralization of the manufacturing industry is far from a scattered sprawl to the outskirts. Rather, four preferred locations for manufacturing sectors can be identified, with each area possessing a leading sector: high-tech manufacturing sectors are located in the inner urban area, followed by machinery and equipment manufacturing sectors in middle areas, with industrial raw materials concentrated in the two outer areas.

\subsection{Service location}

Whereas most manufacturing enterprises were found to have moved out from the inner city, 361,175 service companies $(72.70 \%)$ were identified as being still located inside the Fourth Ring Road. 
Table 3

Fitting results for manufacturing sectors centered between 15 and $20 \mathrm{~km}$ and between 20 and $25 \mathrm{~km}$ away from the city center.

\begin{tabular}{|c|c|c|c|c|c|c|}
\hline \multirow[t]{2}{*}{ Sector } & \multirow[t]{2}{*}{$n_{0}$} & \multirow[t]{2}{*}{$\mathrm{b}$} & \multirow[t]{2}{*}{$\mathbf{b}^{\prime}$} & \multirow[t]{2}{*}{$\mathrm{b}+\mathrm{b}^{\prime}$} & \multicolumn{2}{|l|}{ R Square } \\
\hline & & & & & Exponential & Linear \\
\hline Paper and allied products & $13.65 \%$ & 0.402 & -0.256 & 0.146 & 0.901 & 0.932 \\
\hline Non-ferrous metal Processing & $16.85 \%$ & 0.319 & -0.392 & -0.073 & 0.921 & 0.923 \\
\hline Lumber and wood Products & $22.12 \%$ & 0.608 & -0.414 & 0.194 & 0.906 & 0.8715 \\
\hline Furniture industry & $24.54 \%$ & 0.594 & -0.491 & 0.103 & 0.974 & 0.8705 \\
\hline Petroleum processing & $15.83 \%$ & 0.498 & -0.338 & 0.16 & 0.7675 & 0.815 \\
\hline Stone, clay, and glass products & $12.11 \%$ & 0.484 & -0.263 & 0.221 & 0.8485 & 0.9195 \\
\hline Agro food processing & $15.24 \%$ & 0.476 & -0.23 & 0.246 & 0.92 & 0.9285 \\
\hline Fabricated metal products & $14.98 \%$ & 0.469 & -0.341 & 0.128 & 0.91 & 0.9345 \\
\hline Plastics products & $14.64 \%$ & 0.319 & -0.236 & 0.083 & 0.912 & 0.8715 \\
\hline Chemicals and allied Products & $12.18 \%$ & 0.219 & -0.318 & -0.099 & 0.7295 & 0.809 \\
\hline Food processing & $14.07 \%$ & 0.118 & -0.338 & -0.22 & 0.76 & 0.675 \\
\hline Crafts & $11.36 \%$ & 0.051 & -0.301 & -0.25 & 0.6285 & 0.669 \\
\hline Pens, pencils, and sporting goods & $12.29 \%$ & 0.027 & -0.356 & -0.329 & 0.6215 & 0.6085 \\
\hline Waste materials recycling and processing & $13.12 \%$ & 0.011 & -0.29 & -0.279 & 0.434 & 0.4395 \\
\hline
\end{tabular}

Note: $\mathrm{b}$ for fitting curves from industry centers to the city center; $\mathrm{b}^{\prime}$ for fitting curves from industry centers to the urban periphery.

Most service sectors centers were located between the Second and Third Ring Roads (14 sectors), between the Third and Fourth Ring Roads (13 sectors), and even inside the Fifth Ring Road (3 service sectors). The degree of concentration of service enterprises was also found to be higher than their counterparts in the manufacturing sectors. On average, more than a quarter of service enterprises (26.53\%) were revealed to be located in the same distance from city center, but this value in relation to manufacturing enterprises was only $16.1 \%$. Three categories of service sectors, each centered in different distance, will be analyzed respectively below.

It seems reasonable to assume that most of sectors with centers located between the Second and Third Ring Roads would tend to spread to urban periphery, due to the limited space in the urban core area. However, beside the 5 sectors which were found to have negative values of $b+b^{\prime}, 2$ sectors - the air transportation sector and the insurance sector - in fact had a very large share of the total number of enterprises in their sector $(35.90 \%$ and $29.95 \%$ respectively) located between the Second and Third Ring Roads. The degree of concentration of these two sectors is high in this area. As a result, at least half sectors do not prefer to be outside 3rd ring road. On the other hand, it is true that only a few sectors are able to extend to the city center in an obvious manner - these being the newspaper and publishing sector, and the hotels and other lodging places sector. The b values for these sectors ( 0.241 and 0.081 respectively) were even smaller than those of finance industries like the banking or insurance and security sectors (which generated a b value of $0.472,0.545$ and 0.795 , respectively), as shown in Table 4 . This means that the newspaper and the hotel sectors prefer the urban core area more than the finance industries.

Some sectors appear to strongly prefer to locate outside of the Third Ring Road, rather than inside the Second Ring Road. These sectors, which displayed relatively higher b values and a lower value of $n_{0}$ - like the business services, geological surveying, and miscellaneous transportation services sectors - would, pursuant to our results, be expected to move out from urban core area. However, in general, the $\mathrm{b}^{\prime}$ value of sectors centered in this area was found to be high and their number of firms decreased rapidly outside the Fourth Ring Road.

In contrast, for most of sectors centered between the Third and Fourth Ring Roads, the trend towards spreading to the urban periphery is clear. Although the degree of concentration of these sectors is lower than the degree of concentration amongst sectors centered in the Second and Third Ring Roads, the average absolute value of $b^{\prime}$ is much smaller (0.463and 0.668 respectively), as Table 5 shows. The high b value demonstrates the difficulties faced by hightechnology service sectors to develop in the urban core area. We did, however, also identify sectors which preferred to expand towards the city center, such as the media industry and retail sectors.

At the same time, while sectors inside the Third Ring Road were found to be highly diversified, high-technology service industries were found to be main theme between Third and Fourth Ring Roads. Six sectors related to technology service are centered in this

Table 4

Fitting results for service sectors centered in between the Second and Third Ring Roads.

\begin{tabular}{|c|c|c|c|c|c|c|}
\hline \multirow[t]{2}{*}{ Sector } & \multirow[t]{2}{*}{$n_{0}$} & \multirow[t]{2}{*}{ B } & \multirow[t]{2}{*}{$\mathrm{b}^{\prime}$} & \multirow[t]{2}{*}{$\mathrm{b}+\mathrm{b}^{\prime}$} & \multicolumn{2}{|l|}{ R Square } \\
\hline & & & & & Exponential & Linear \\
\hline Newspaper and publishing & $33.85 \%$ & 0.241 & -1.67 & -1.429 & 0.705 & 0.7905 \\
\hline Security and commodity brokers & $38.04 \%$ & 0.795 & -1.355 & -0.56 & 0.6375 & 0.768 \\
\hline Water transportation & $41.28 \%$ & 1.281 & -1.704 & -0.423 & 0.742 & 0.7625 \\
\hline Hotels and other lodging places & $26.14 \%$ & 0.081 & -0.337 & -0.256 & 0.931 & 0.8215 \\
\hline Eating and drinking places & $24.48 \%$ & 0.37 & -0.387 & -0.017 & 0.9725 & 0.8585 \\
\hline Other finance activities & $28.85 \%$ & 0.369 & -0.353 & 0.016 & 0.963 & 0.8085 \\
\hline Social services & $23.17 \%$ & 0.487 & -0.409 & 0.078 & 0.984 & 0.875 \\
\hline Geological survey & $25.00 \%$ & 1.281 & -1.08 & 0.201 & 0.649 & 0.874 \\
\hline Insurance & $29.55 \%$ & 0.545 & -0.344 & 0.201 & 0.945 & 0.797 \\
\hline Banking & $22.41 \%$ & 0.472 & -0.265 & 0.207 & 0.969 & 0.866 \\
\hline Postal services & $21.19 \%$ & 0.513 & -0.288 & 0.225 & 0.977 & 0.885 \\
\hline Miscellaneous transportation services & $23.63 \%$ & 0.767 & -0.485 & 0.282 & 0.9645 & 0.8725 \\
\hline Business services & $25.39 \%$ & 0.733 & -0.368 & 0.365 & 0.975 & 0.8555 \\
\hline Air transportation & $35.90 \%$ & 1.091 & -0.587 & 0.504 & 0.8985 & 0.855 \\
\hline
\end{tabular}

Note: $\mathrm{b}$ for fitting curves from industry centers to the city center; $\mathrm{b}^{\prime}$ for fitting curves from industry centers to the urban periphery. 
Table 5

Fitting results for service sectors centered between the Third and Fourth Ring Roads.

\begin{tabular}{|c|c|c|c|c|c|c|}
\hline \multirow[t]{2}{*}{ Sector } & \multirow[t]{2}{*}{$n_{0}$} & \multirow[t]{2}{*}{$\mathrm{b}$} & \multirow[t]{2}{*}{$\mathrm{b}^{\prime}$} & \multirow[t]{2}{*}{$\mathrm{b}+\mathrm{b}^{\prime}$} & \multicolumn{2}{|l|}{ R Square } \\
\hline & & & & & Exponential & Linear \\
\hline Media industry & $29.42 \%$ & 0.319 & -1.166 & -0.847 & 0.936 & 0.825 \\
\hline Urban public transport & $20.62 \%$ & 0.127 & -0.407 & -0.28 & 0.6435 & 0.7005 \\
\hline Retail & $23.12 \%$ & 0.253 & -0.39 & -0.137 & 0.956 & 0.8575 \\
\hline Real estate & $20.24 \%$ & 0.338 & -0.342 & -0.004 & 0.943 & 0.8265 \\
\hline Wholesale trade & $21.55 \%$ & 0.337 & -0.335 & 0.002 & 0.877 & 0.776 \\
\hline Research and Testing & $22.11 \%$ & 0.451 & -0.434 & 0.017 & 0.892 & 0.814 \\
\hline Culture industry & $24.94 \%$ & 0.448 & -0.424 & 0.024 & 0.974 & 0.849 \\
\hline Communication & $26.72 \%$ & 0.47 & -0.407 & 0.063 & 0.9755 & 0.876 \\
\hline Computer services & $29.96 \%$ & 0.574 & -0.453 & 0.121 & 0.854 & 0.785 \\
\hline Railroad transportation & $27.04 \%$ & 0.631 & -0.317 & 0.314 & 0.904 & 0.7835 \\
\hline Technology promotion services & $27.02 \%$ & 0.734 & -0.413 & 0.321 & 0.91 & 0.7765 \\
\hline Software & $33.48 \%$ & 0.926 & -0.435 & 0.491 & 0.7895 & 0.729 \\
\hline Engineering and management services & $32.42 \%$ & 1.055 & -0.492 & 0.563 & 0.77 & 0.703 \\
\hline
\end{tabular}

Note: $b$ for fitting curves from industry centers to the city center; $b^{\prime}$ for fitting curves from industry centers to the urban periphery.

area, including the engineering and management services sector, and the software and research and testing sector.

Only three service industries (the warehousing, road transportation, and equipment rental and leasing sectors) were found to have centers outside the Fourth Ring Road. With a relatively low degree of concentration at a distance from the city center, results indicate that these sectors prefer to be located outside the Fourth Ring Road, as Table 6 shows. The reason for this apparent preference lies in their spatial needs: compared to other service industries, these three sectors require large spaces to store goods or equipment, and good accessibility to highways. As such, their preferred locations are similar to those of the manufacturing industries.

To sum up, our analysis revealed service sectors to be more concentrated in Beijing than manufacturing sectors are. Whereas 27 service sectors were found to be centered in two adjacent zones (with the average degree of concentration 26.53\% in two zones), only 22 manufacturing sectors were identified as being centered in two non-adjacent zones (with an average degree of concentration of $16.10 \%$ ). Moreover, although most service sectors appear to be expanding toward the periphery, the mass media industries such as newspaper and broadcasting and mass consumption industries such as retail, hotels, and restaurants were found to tend to expand towards the city center. This city-ward expansion and clustering of mass consumption industries and the public sector (for instance, social services and postal services) within the Third Ring Road does not, strangely, reflect the suburbanization of population in Beijing (Feng et al., 2008; Zhou \& Ma, 2000).

\subsection{The spatial distribution of industries in Beijing}

Having identified the spatial distribution of enterprises within various sectors within Beijing, distribution curves for each sector can be fitted (see Fig. 3). These curves illustrate the locational characteristics of each sector in continuous space. The most preferred location for every sector can be found by overlaying these distribution curves and an overall spatial distribution pattern of industries in Beijing can ultimately be depicted on the basis of industrial location, such as the one presented at Fig. 4.

We consider that the share of one specific sector in one area reveals its preference for that place. Industrial preference for certain locations is based on not only on rental affordability, but also on other factors related to the planned economy such as zoning and accessibility, which are equally important to economic forces in reality. The final picture does not include all the sectors mentioned above. The reason for the omission of some sectors is that their spatial distribution was found to be relatively even (this is the case for, for instance, social services), or the city center was not found to exert a significant impact on their location. As a result, 41 sectors make up the composite figure at Fig. 4, which largely reflects the industrial spatial structure in Beijing.

Sectors, moving outwards from the city center, are as follows: hotels and other lodging places; eating and drinking places; newspaper and publishing; security and commodity brokers; air transportation and water transportation; security and commodity brokers; insurance and other finance activities; geological survey; business services; media industry; engineering and management services; software, computer services, and communication; engineering and management services; railroad transportation; computer and communication equipment and instruments and office equipment; research and testing; technology promotion services; printing; warehousing and road transportation; apparel and other textile products and leather and leather products; electronics and other electric equipment; special industry machinery and industrial machinery and equipment; transportation equipment; paper and allied products; non-ferrous metal processing; paper and allied products; pens, pencils, and sporting goods and crafts; food processing; chemicals and allied products; lumber and wood products; furniture industry; lumber and wood products; petroleum processing; fabricated metal products; stone, clay, and glass products; agro food processing; beverages.

Normally, most service sectors would be expected to be found to locate close to the city center, and most manufacturing sectors to be inclined to locate further out, as shown in Fig. 4. Two service

Table 6

Fitting results for service sectors centered between the Fourth and Fifth Ring Roads.

\begin{tabular}{|c|c|c|c|c|c|c|}
\hline \multirow[t]{2}{*}{ Sector } & \multirow[t]{2}{*}{$n_{0}$} & \multirow[t]{2}{*}{$\mathrm{b}$} & \multirow[t]{2}{*}{$\mathrm{b}^{\prime}$} & \multirow[t]{2}{*}{$\mathrm{b}+\mathrm{b}^{\prime}$} & \multicolumn{2}{|l|}{ R Square } \\
\hline & & & & & Exponential & Linear \\
\hline Warehousing & 0.225 & 0.828 & -0.309 & 0.519 & 0.966 & 0.878 \\
\hline Road transportation & 0.190 & 0.466 & -0.241 & 0.225 & 0.9265 & 0.8605 \\
\hline Equipment rental and leasing & 0.168 & 0.408 & -0.31 & 0.098 & 0.921 & 0.919 \\
\hline
\end{tabular}




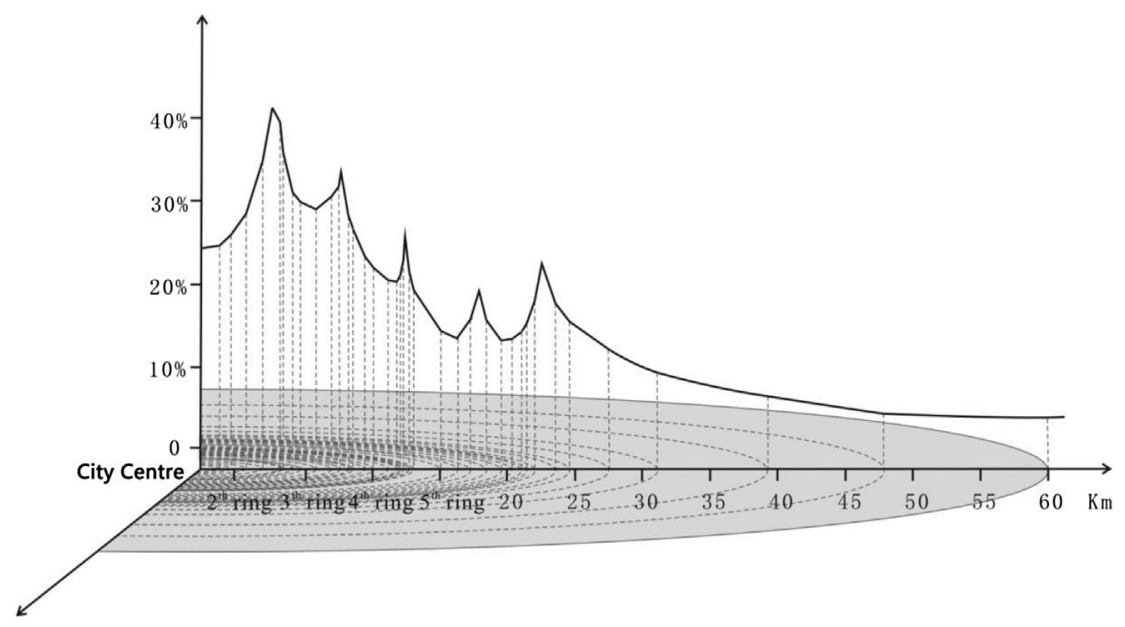

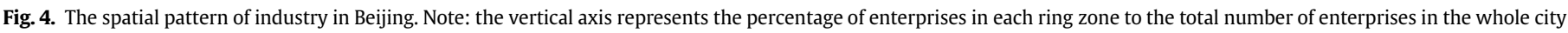
for a certain sector.

industry centers were found to be located in the inner urban area of Beijing: the Central Business District (CBD) and the Zhongguancun Science Park (ZSP). Planned and developed since 1998, the CBD now hosts more than 19,000 enterprises, producing service enterprises such as PwC and McKinsey \& Company; the R\&D facilities of HP Sumsung; the headquarters of Shell, Toyota, GM; as well as media companies such as CCTV, VOA, BTV, BBC, CNN, and the Wall Street Journal. The Zhongguancun Science Park has, over more than 30 years, developed to become the largest cluster of semiconductor, computer, and telecommunication enterprises in China (Liefner et al., 2006; Zhou, 2005). Now, many famous technology enterprises such as Microsoft, Oracle, and Intel have established R \& D institutions. A number of high-tech manufacturing sectors are also centered in this area. Next to the ZSP is a manufacturing center which is dominated by machinery industry. Raw industry, as well as some light industrial activities, are located in Beijing's two outermost centers.

Several unique characteristics appear through this analysis, especially in relation to Beijing's urban core area. Firstly, it is noteworthy that, in Beijing's case, the center of the urban spatial structure cannot be viewed as the city's economic center. The total number and density of enterprises within the First Ring Road is 54,554 and $877.92 / \mathrm{km}^{2}$, respectively. These figures are significantly less than those $\left(105,509\right.$ and $\left.1091.10 / \mathrm{km}^{2}\right)$ found between Second and Third Ring Roads, as shown at Fig. 5. In fact, the urban core area was not found to be the most preferred location for any sector. The city's CBD is in reality located between Second and Third Ring Roads in the master plan for Beijing. Some may argue that this kind of industrial structure means that whilst Beijing's CBD is not located in the geographic center of the city (and in this sense it is unlike a city like Chicago), industrial rings are still generated from the CBD. The figure above seems to support this viewpoint. However, indeed almost all industrial sectors are present in the city's geographic center, including finance and business. This study locates two finance and business clusters (the CBD and Jinrongjie) in Beijing, on the eastern and western sides of Tiananmen Square. The former host a large number of foreign banks and offices, and the latter nearly all of the headquarters of major state-owned banks and financial regulators. Both centers are thus part of the urban core area where the central government, Zhongnanhai (China's White House), is located. Furthermore, the transport accessibility of the urban core area in Beijing is particularly high, as a result of the six ring roads which surround it and the radial roads which begin from it. Secondly, results indicate that newspaper and publishing companies, as well as hotels and restaurants, prefer to locate within urban core more strongly than banks, insurance, and business enterprises do. Thirdly, whilst sectors servicing residents should have clustered in the places with the largest populations, this study indicates that sectors such as the social services and postal service are rather centered between Second and Third Ring Roads where business and finance enterprises are located. Beside this, retail companies, restaurants and hotels also spread to the city center rather than the periphery. These phenomena are a little strange given the suburbanization trends that have been documented in Beijing by previous studies, as detailed earlier in the paper.

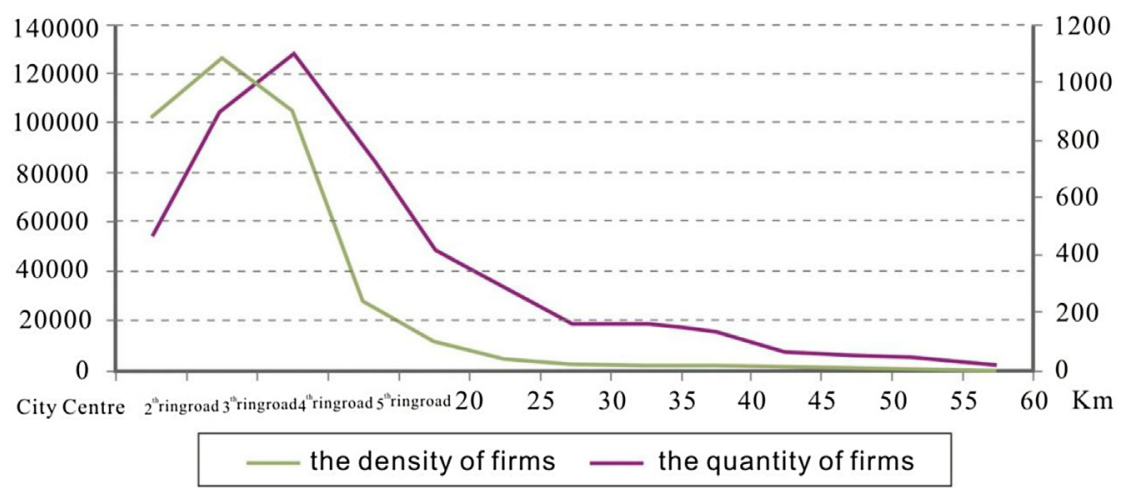

Fig. 5. The quantity and density of firms with respect to distance from city center. 


\section{Three driving forces: government interventions and market forces}

Government intervention has a significant impact on industrial spatial distribution in three ways: as an information center, through zoning, and through the remains of the planned economy. The notion an information center, the first impact of government intervention, relates to the manner in which public policies affect economic activities, namely in terms of the mechanism of action of public policies. It is this which determines that the government, rather than $\mathrm{CBD}$, is located in the city center of Beijing. The Chinese government should be regarded as the information center of economic development in China, as it has a decisive influence on the amount and direction of investment, as well as the selection of key sectors for future development, and - importantly - because it exerts influence directly on economic objects, not merely through or via the market. For example, in China, central as well as local governments often develop plans to outline key economic and development targets for the country, for cities and even for specific industries - an example of which is China's Five-Year Plan (FYP), which announced by the central government every five years. Many of these targets are accompanied by specific administrative instructions, like the target of 7\% annual GDP growth which is set out within the 13th FYP. Whether or not local governments are capable of achieving this objective determines the promotion of local officials. As such, local governments try their best to achieve these goals by many means. The direct government investment and business investment promoted by governments are popular. Nevertheless, the market is also important. The market will provide a lot of important information feedback for the further adjustment of public policies. Currently, city centers are not merely nodes of high accessibility for industrial transport but also centers for information production (Castells, 1975; Scott, 1982). As such, as the most important information source, the government must be placed at the city center, where most economic activities are undertaken. This pattern is thus, in our view, reasonable in Beijing.

The second means by which the government exerts influence over industrial spatial distribution is through the mechanisms of zoning. It is a common practice for governments internationally to plan urban land use. The same is true in China. Land-use planning has significant influence with respect to the urban core of Beijing. In order to make the Tiananmen rostrum looks majestic, the height of buildings inside the Second Ring Road is strictly limited by zoning laws. The direct result of this zoning is apparent in the relatively lower density of firms who locate in the urban core area. To a certain degree, the zoning laws which guide development in the urban core area can be seen as being directly responsible for a large number of finance and business enterprises being located between the Second and the Third Ring Roads and a lot of luxury hotels and restaurants preferring the urban core area. Beyond these effects, zoning also promotes the decentralization of manufacturing industries through land supply mechanisms. Whereas the local government provides $12.49 \mathrm{~km}^{2}$ of industrial land between Fourth and Fifth Ring Roads, this figure declines significantly - to 0.24 , 0.51 , and 1.79 , respectively - in the urban core area, between the Second and Third Ring Roads and between the Third and Fourth Ring Roads.

As the result of urban zoning and planning, many development zones and new towns have been constructed within the three primary locational concentrations of major manufacturing industries. Situated between the Third and Fourth Ring Roads, Zhongguancun Sicence Park (ZSP) has agglomerated a high degree of ICT activities since the 1980s, and has become the largest ICT cluster and ICT innovation center in China (Tan, 2006; Wang, Cheng, \& Ganapati, 2012; Zhou, 2005). ZSP's success is largely attributed to a large number of top research institutions which are close to the park. The first master plan for Beijing in 1954 laid a firm base for the development of the ZSP, which was planned from the beginning as a cluster of institutions and universities. Three important industrial clusters exist between the Fourth and Fifth Ring Roads, and these can be seen clearly in Fig. 1. Fengtai industrial park (ZSP) and Dianzicheng are the first development zones, designed as ZSP sub-parks in 1994 and 1999 respectively. Further, Fatou industrial park was also seen as one of the five most important manufacturing districts. Similar conditions existed in the area between 20 and $25 \mathrm{kms}$ from the city center, where 4 out of 11 new towns and the Beijing Economic and Technological Development Area (BDA) and its expansion (the biggest economic and technical area in Beijing) are also located.

Although the traditional Chinese planned economic system has been replaced by a market economy in the past 30 years, some remnants of the planned economy remain, which are helpful in understanding the spatial distribution sectors dominated by stateowned enterprises, such as the newspaper and publishing sector and the geological survey sector. Of a total of 3816 newspaper and publishing enterprises, 3009 out are state-owned, and of the 102

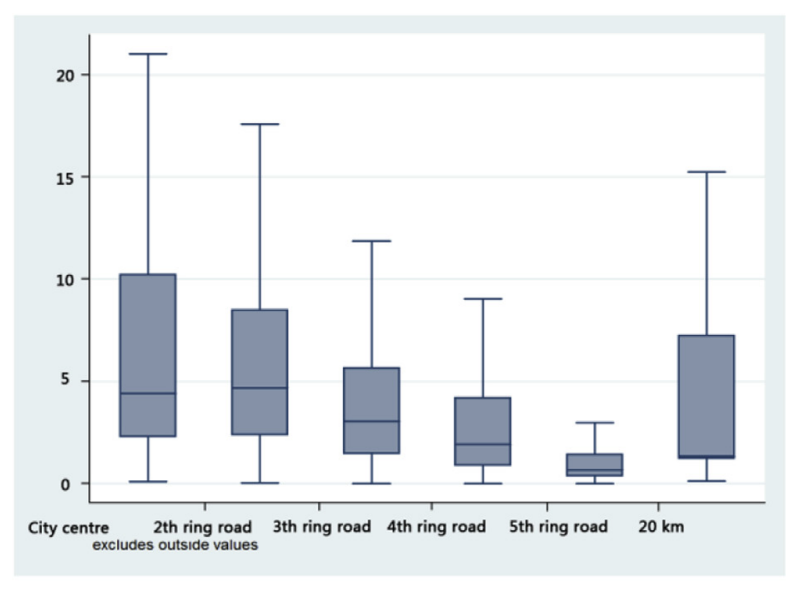

(a) Price per unit of commercial land

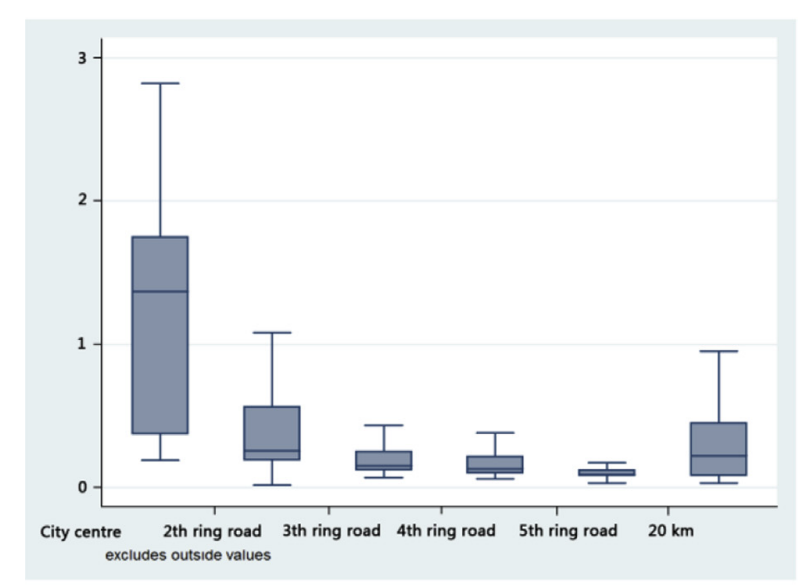

(b) Price per unit of industrial land

Fig. 6. The change in unit land price $\left(1000 ¥ / \mathrm{m}^{2}\right)$ across ring zones. 
geological survey enterprises in Beijing 43 out are state-owned. These are clustered between the Second and Third Ring Roads, the same place where clusters of business and finance enterprises can be found. To our knowledge, few studies show that the coagglomeration between finance and publishing or geological survey companies is driven by knowledge spillovers. In addition, generally these two sectors could not afford the rent of between Second and Third Ring Roads, which incur the highest land prices, as shown in Fig. 6. These (mainly state-owned) enterprises can afford the high land prices of the city center because the government provided the land for free in the period of planned economy. Furthermore, the importance of these sectors to the country also contributes to their location close to the city's center. Newspaper and publishing and media industries play an important role in national stability; and geological survey is related to the exploration and measurement of natural resource, which constitutes a state secret.

Last but not least, market force has contributed to shaping the overall industrial spatial pattern in Beijing. As Zheng and Kahnm (2007) attest, the classic urban monocentric model still works in Beijing. Both commercial and industrial land prices decline with the distance from city center, as Fig. 6 shows. It is possible to demonstrate that the price of land has largely shaped the overall spatial pattern of industries in Beijing. Changes in commercial/industrial land prices across the ring roads are also shown at Fig. 6, whereby land prices decline steadily with increasing distance from the city center, rising slightly in the outermost ring. As such, market forces exert a fundamental influence on industrial spatial distribution in Beijing. For example, the dominant sectors between the Second and Third Ring Roads are insurance, banking, and business services, which are highly profitable sectors, and a few manufacturing enterprises - these are all located in urban core area as a result of the fact that this location maintains the highest land prices in the city.

In summary, the broad pattern of industrial activity generally complies with the laws of the market economy, and the influence of government interventions is, in comparison, mainly shown in specific local areas, such as the urban core area and the development zones. Since China adopted wide-reaching economic reforms in 1978, the country has gradually transformed its planned economy into a market economy. The government merely exerts its influence on industrial space through the development of some strategic points, no longer controlling the industrial spatial distribution by allocating land for each enterprise. As such, the unique characteristics of Beijing - those which set it apart from other cities in terms of its industrial spatial distribution - can, as a result (and as mentioned above) be considered to result from the influence of the government.

\section{Concluding comments}

In general, the results of the study detailed in this paper indicate that the industrial spatial structure of Beijing conforms to the classic monocentric model, but also maintains some unique characteristics. These findings can be regarded as providing evidence of the effects exerted by the significant dual-forces of the state and the market on industrial location in the transitional economy.

In Beijing, market forces dominate the overall distribution pattern of the manufacturing and service industries, whereas government intervention wields influence merely in local areas. This, however, does not mean that the role of government can be neglected in industrial location choice. In fact, the influence of government is quite obvious in the urban core area. The operating mechanisms of public policy in China, which deviate markedly from those seen in countries with market economies, contribute to the core status of central government in economic decision-making processes. The central government as such takes the place of the CBD and occupies the city center of Beijing. The remains of a planned economy and planning controls from central and local governments are also important reasons which can explain why sectors in Beijing's core area vary from those in Western cities. Furthermore, the central government and its affiliations, located in the core area of Beijing, attract almost all possible types of economic activities, acting like a huge magnet. As a result, Beijing has failed to become a multi-center city and has suffered greatly from the so-called "Big City Diseases" of congestion, air pollution, and high housing prices.

However, the result of government intervention does not always go against the law of the market economy. The establishment of development zones and new towns, as a governmental behavior, reinforces and speeds up the marketization process. As a result, the location of Beijing's manufacturing industries is very similar to that of western cities. Government intervention is thus necessary to adjust and optimize the spatial distribution of economic activities in China's economic and urban transformation. The layout of urban space of almost all the other Chinese cities has followed a similar pattern to that of Beijing. One particular common feature of those cities is the ring roads, which start from the core areas where the local government is situated. The analysis set out in this paper is therefore helpful in understanding better the spatial distribution of industrial activities in almost all Chinese cities. When socioeconomic development reaches the developed stage, there will be a sensible industrial distribution in Chinese cities. At that point, market power can be expected to overwhelm the government's ability to exert influence over the location of industry.

\section{Author notes}

No conflict of interest exits in the manuscript, and the manuscript is approved by all authors for publication. I would like to declare on behalf of my co-authors that the work described was original and has not been submitted or published elsewhere. We investigate the industrial pattern in the Beijing Metropolitan area by using specialized, sectoral-locational data. The industrial spatial pattern is the spatial reflection of economic activities which are affected significantly by a dual power of government and market. Therefore, this paper attempts to reveal the influence of government and market forces from the perspective of industrial space.

\section{Acknowledgments}

This work was supported by the State Key Program of National Natural Science of China, under Grant No. 41230632 and the National Natural Science Foundation of China under Grant No. 41301123 and No. 41201169.

\section{References}

Alonso, W. (1960a). A model of the urban land market: Location and densities of dwellings and businesses. Ph.D. dissertation. University of Pennsylvania.

Alonso, W. (1960b). A theory of the urban land market. Papers in Regional Science, 6, 149-157.

Alonso, W. (1964). Location and land use: Toward a general theory of land rent. Cambridge, MA: Harvard University Press.

Anas, A., Arnott, R., \& Small, K. A. (1998). Urban spatial structure. Journal of Economic Literature, 36, 1426-1464.

Archer, W. R., \& Smith, M. T. (2003). Explaining location patterns of suburban offices. Real Estate Economics, 31, 139-164.

Balchin, P. N., Bull, G. H., Kieve, J. L., \& Balchin, P. N. (1995). Urban land economics and public policy. Houndmills, Basingstoke, Hampshire: Macmillan.

Bertaud, A., \& Brueckner, J. K. (2005). Analyzing building-height restrictions: predicted impacts and welfare costs. Regional Science and Urban Economics, 35, 109-125.

Bertaud, A., \& Renaud, B. (1997). Socialist cities without land markets. Journal of Urban Economics, 41, 137-151. 
Brown, S. (1993). Retail location theory: evolution and evaluation. International Review of Retail, Distribution and Consumer Research, 3, 185-229.

Castells, M. (1975). Sociologie de l'espace industriel. Paris: Anthropos.

Cheng, F., Boerboom, L., \& Geertman, S. (2012). Changing spatial concentration of sectoral employment in China's Pearl River Delta 1990-2005. Tijdschrift Voor Economische En Sociale Geografie, 104, 261-277.

Chudzynska, I. (1981). Locational specialization of retail trade functions in Warszawa. Environment and Planning A, 13, 929-942.

Clark, Colin (1951). Urban population densities. J. R. Stat. Soc., 114, 490-496. Series A (General).

Craig, S. G., \& Ng, P. T. (2001). Using quantile smoothing splines to identify employment subcenters in a multicentric urban area. Journal of Urban Economics, 49, 100-120.

Cropper, M. L., \& Gordon, P. L. (1991). Wasteful commuting: a re-examination. Journal of Urban Economics, 29, 2-13.

Dear, M. (2002). Los Angeles and the Chicago School: invitation to a debate. City \& Community, 1, 5-32.

Ding, C. (2004). Urban spatial development in the land policy reform era: evidence from Beijing. Urban Studies, 41, 1889-1907.

Dubin, R. A., \& Sung, C.-H. (1987). Spatial variation in the price of housing: rent gradients in non-monocentric cities. Urban Studies, 24, 193-204.

Dunse, N., Jones, C., Brown, J., \& Fraser, W. D. (2005). The spatial pattern of industrial rents and the role of distance. Journal of Property Investment \& Finance, 23, $329-341$.

Egan, D. J., \& Nield, K. (2000). Towards a theory of intraurban hotel location. Urban Studies, 37, 611-621.

Ellson, R., \& McDermott, J. (1987). Zoning uncertainty and the urban land development firm. Journal of Urban Economics, 22, 209-222.

Feng, J., \& Zhou, Y. (2005). Suburbanization and the changes of urban internal spatial structure in Hangzhou, China. Urban Geography, 26, 107-136.

Feng, J., Zhou, Y., \& Wu, F. (2008). New trends of suburbanization in Beijing since 1990: from government-led to market-oriented. Regional Studies, 42, 83-99.

Fujita, M. (1986). Urban land use theory. In Location theory (pp. 3-149). Harwood Academic Publishers.

Gao, B. Y., Liu, W. D., \& Dunford, M. (2014). State land policy, land markets and geographies of manufacturing: the case of Beijing, China. Land Use Policy, 36, $1-12$.

Greene, R. P., \& Pick, J. B. (2011). Exploring the urban community: A GIS approach. Pearson Prentice Hall.

Grimaud, A. (1989). Agglomeration economies and building height. Journal of Urban Economics, 25, 17-31.

Gu, C., Wang, F., \& Liu, G. (2005). The structure of social space in Beijing in 1998: a socialist city in transition. Urban Geography, 26, 167-192.

Hills, R. M., Jr., \& Schleicher, D. (2010). The steep costs of using noncumulative zoning to preserve land for urban manufacturing. The University of Chicago Law Review, 249-273.

Hsu, C.-I., \& Guo, S.-P. (2001). Household-mode choice and residential-rent distribution in a metropolitan area with surface road and rail transit networks. Environment and Planning A, 33, 1547-1576.

Huang, H., \& Wei, Y. D. (2014). Intra-metropolitan location of foreign direct investment in Wuhan, China: institution, urban structure, and accessibility. Applied Geography, 47, 78-88.

Jiang, F., Liu, S., Yuan, H., \& Zhang, Q. (2007). Measuring urban sprawl in Beijing with geo-spatial indices. Journal of Geographical Sciences, 17, 469-478.

Jones, D. W., McGuire, W., \& Witte, A. (1991). An introduction to the Thünen location and land use model. Research in Marketing, 5, 35-70.

Kemper, P., \& Schmenner, R. (1974). The density gradient for manufacturing industry. Journal of Urban Economics, 1, 410-427.

Li, S.-M. (2000). Housing consumption in urban China: a comparative study of Beijing and Guangzhou. Environment and Planning A, 32, 1115-1134.

Liefner, I., Hennemann, S., \& Xin, L. (2006). Cooperation in the innovation process in developing countries: empirical evidence from Zhongguancun, Beijing. Environment and Planning A, 38, 111-130.

Liu, X., Han, S. S., \& O'Connor, K. (2013). Art villages in metropolitan Beijing: a study of the location dynamics. Habitat International, 40, 176-183.

Ma, L. J. (2002). Urban transformation in China, 1949-2000: a review and research agenda. Environment and Planning A, 34, 1545-1570.

Ma, L. J. (2004). Economic reforms, urban spatial restructuring, and planning in China. Progress in Planning, 61, 237-260.

Pacione, M. (2005). Urban geography: A global perspective. Taylor \& Francis.

Peiser, R. B. (1987). The determinants of nonresidential urban land values. Journal of
Urban Economics, 22, 340-360.

Ren, X., \& Sun, M. (2012). Artistic urbanization: creative industries and creative control in Beijing. International Journal of Urban and Regional Research, 36, 504-521.

Richardson, H. W. (1977). On the possibility of positive rent gradients. Journal of Urban Economics, 4, 60-68.

Riley, R. (1997). Central area activities in a post-communist city: Lodz, Poland. Urban Studies, 34, 453-470.

Scott, P. (1967). Geography and retailing. Transaction Publishers.

Scott, A. J. (1982). Locational patterns and dynamics of industrial activity in the modern metropolis. Urban Studies, 19, 111-141.

Shi, Y. S., \& Huang, Y. C. (2012). Relationship between morphological characteristics and land-use intensity: empirical analysis of Shanghai development zones. Journal of Urban Planning and Development, 139, 49-61.

Sivitanidou, R. (1996). Do office-commercial firms value access to service employment centers? A hedonic value analysis within polycentric Los Angeles. Journal of Urban Economics, 40, 125-149.

Tan, J. (2006). Growth of industry clusters and innovation: lessons from Beijing Zhongguancun Science Park. Journal of Business Venturing, 21, 827-850.

Tan, M., Li, X., Xie, H., \& Lu, C. (2005). Urban land expansion and arable land loss in China-a case study of Beijing-Tianjin-Hebei region. Land use policy, 22, 187-196.

Tian, G., Wu, J., \& Yang, Z. (2010). Spatial pattern of urban functions in the Beijing metropolitan region. Habitat International, 34, 249-255.

Tisdell, C. (2009). Economic reform and openness in China: China's development policies in the last 30 years. Economic Analysis \& Policy, 39, 271-294.

Wang, J., Cheng, S., \& Ganapati, S. (2012). Path dependence in regional ICT innovation: differential evolution of Zhongguancun and Bangalore. Regional Science Policy \& Practice, 4, 231-245.

Wang, L., Kundu, R., \& Chen, X. (2010). Building for what and whom? New town development as planned suburbanization in China and India. Research in Urban Sociology, 10, 319-345.

Wei, Y. H. D., Leung, C. K., Li, W. M., \& Pan, R. (2008). Institutions, location, and networks of multinational enterprises in China: a case study of Hangzhou. Urban Geography, 29, 639-661.

Wong, K., \& Zhao, X. (1999). The influence of bureaucratic behavior on land appointment in China: informal process. Environment and Planning C: Government and Policy, 17, 113-126.

Wu, F. (1999). Intrametropolitan FDI firm location in Guangzhou, China A poisson and negative binomial analysis. The Annals of Regional Science, 33, 535-555.

Wu, F., \& Phelps, N. A. (2011). (Post) suburban development and state entrepreneurialism in Beijing's outer suburbs. Environment and Planning A, 43, 410-430.

Wu, J. P., \& Radbone, I. (2005). Global integration and the intra-urban determinants of foreign direct investment in Shanghai. Cities, 22, 275-286.

Wu, F., \& Yeh, A. G.-O. (1997). Changing spatial distribution and determinants of land development in Chinese cities in the transition from a centrally planned economy to a socialist market economy: a case study of Guangzhou. Urban Studies, 34, 1851-1879.

Wu, F., \& Yeh, A. G.-O. (1999). Urban spatial structure in a transitional economy: the case of Guangzhou, China. Journal of the American Planning Association, 65, 377-394.

Xiao, R., Weng, Q., Ouyang, Z., Li, W., Schienke, E. W., \& Zhang, Z. (2008). Land surface temperature variation and major factors in Beijing, China. Photogrammetric Engineering and Remote Sensing, 74, 451.

Ye, L. (2011). Urban regeneration in China: policy, development, and issues. Local Economy, 26, 337-347.

Ye, L. (2014). Examining China's urban redevelopment: land types, targeted policies, and public participation. In U. Altrock, \& S. Schoon (Eds.), Maturing megacities (pp. 123-138). Springer.

Yeup Kim, J., \& Zhang, L. Y. (2008). Formation of foreign direct investment clustering-a new path to local economic development? The case of Qingdao. Regional Studies, 42, 265-280.

Zheng, S. Q., \& Kahnm, M. E. (2007). Land and residential property markets in a booming economy: new evidence from Beijing. Journal of Urban Economics, 63, $743-757$.

Zhou, Y. (2005). The making of an innovative region from a centrally planned economy: institutional evolution in Zhongguancun Science Park in Beijing. Environment and Planning A, 37, 1113-1134.

Zhou, Y., \& Ma, L. J. (2000). Economic restructuring and suburbanization in China. Urban Geography, 21, 205-236. 